\title{
Flora da Bahia: Marcgraviaceae
}

\author{
Michella Del Rei Teixeira ${ }^{1,2^{*}}$, Pedro Fiaschi ${ }^{3}$ \& André Márcio Amorim ${ }^{2,4}$ \\ ${ }^{1}$ Laboratório de Taxonomia Vegetal, Departamento de Ciências Biológicas, Universidade Estadual de Feira de \\ Santana, Feira de Santana, Bahia, Brasil. \\ 2 Departamento de Ciências Biológicas, Universidade Estadual de Santa Cruz, Ilhéus, Bahia, Brasil. \\ 3 Departamento de Botânica, Centro de Ciências Biológicas, Universidade Federal de Santa Catarina, \\ Florianópolis, Santa Catarina, Brasil. \\ ${ }^{4}$ Herbário CEPEC, CEPLAC, Ilhéus, Bahia, Brasil.
}

\begin{abstract}
Resumo - É apresentado o levantamento florístico de Marcgraviaceae para o estado da Bahia. Foram reconhecidos quatro gêneros e oito espécies: Marcgravia coriacea, M. polyantha, Norantea guianensis, Schwartzia adamantium, S. brasiliensis, S. geniculatiflora, S. jucuensis e Souroubea guianensis. São apresentadas chaves de identificação de gêneros e espécies, descrições, mapas de distribuição, ilustrações e comentários das espécies. O gênero Norantea é registrado pela primeira vez no Estado.
\end{abstract}

Palavras-chave adicionais: florística, Marcgravia, Nordeste, Schwartzia, taxonomia.

\begin{abstract}
Flora of Bahia: Marcgraviaceae) - The floristic account of the Marcgraviaceae from Bahia State is presented. Four genera and eight species were registered: Marcgravia coriacea, M. polyantha, Norantea guianensis, Schwartzia adamantium, S. brasiliensis, S. geniculatiflora, S. jucuensis, and Souroubea guianensis. Identification keys and descriptions are presented for genera and species, as well as geographic distribution maps in the state, illustrations, and general comments on the species. The genus Norantea is recorded in Bahia for the first time.
\end{abstract}

Additional key words: floristics, Marcgravia, Northeastern Region, Schwartzia, taxonomy.

\section{MARCGRAVIACEAE}

Arbustos escandentes, lianas, hemiepífitas ou arvoretas; ramos monomórficos ou dimórficos, geralmente lenticelados. Folhas simples, alternas, dísticas ou espiraladas, não estipuladas; sésseis ou pecioladas; lâmina com glândulas de distribuição geralmente irregular na face abaxial; venação pinada, broquidódroma. Inflorescências terminais, raro caulifloras, racemosas, muitas vezes semelhantes a umbelas ou espigas. Brácteas sésseis ou pediceladas transformadas em nectários extraflorais de coloração variável, com ou sem flor fértil. Flores hermafroditas, actinomorfas, diclamídeas; bractéolas 2, sepaloides; sépalas (4)5, persistentes nos frutos, livres ou conatas na base, imbricadas; pétalas (3)4 ou 5(6), livres, conatas na base ou em caliptra (Marcgravia), imbricadas; estames 3 a numerosos, uni a trisseriados, filetes livres ou conatos na base, anteras rimosas; ovário súpero, bi a pluricarpelar, placentação axial ou parietal, placenta invaginante; óvulos numerosos. Frutos globosos ou cônicos, capsulares, deiscência irregular; epicarpo coriáceo; sementes numerosas, reniformes, semilunares ou oblongas e ligeiramente curvas.

Marcgraviaceae possui oito gêneros e cerca de 130 espécies de distribuição exclusivamente

\footnotetext{
*Autora para correspondência: michelladelrei@yahoo.com.br Editor responsável: Julio Lombardi

Submetido: 11 mar. 2013; aceito: 10 jun. 2013

Publicação inicial 27 jul. 2013; versão final: 2 maio 2014
}

neotropical, sendo encontrada desde o sul do México até o norte da Bolívia e o sul do Brasil (Giraldo-Cañas 1999, 2007; Picca \& Giraldo-Cañas 1999; Dressler 2004). No Brasil, ocorrem seis gêneros e cerca de 38 espécies, com registros em todos os Estados (Souza 2012). No estado da Bahia, a família está representada por quatro gêneros e oito espécies, que são encontradas na Mata Atlântica, Cerrado, campos rupestres e Caatinga.

\section{Chave para os gêneros}

1. Folhas alternas dísticas; inflorescência umbeliforme; nectários sem flor fértil; flores tetrâmeras, pétalas conatas em caliptra .

1. Marcgravia

1'. Folhas alternas espiraladas; inflorescência racemosa; nectários sempre com uma flor fértil; flores pentâmeras, pétalas livres ou conatas na base.

2. Nectários com aurículas na base, inseridos no ápice do pedicelo floral, logo abaixo do cálice....

4. Souroubea

2'. Nectários sem aurículas na base, inseridos entre o terço proximal e o terço distal do pedicelo floral.

3. Flores com pedicelo $\leq 1 \mathrm{~cm}$ compr.; nectário $\geq 2,5 \mathrm{~cm}$ compr., inserido na porção mediana ou no terço distal do pedicelo floral

2. Norantea

3'. Flores com pedicelo $\geq 1,5 \mathrm{~cm}$ compr.; nectário $\leq 2 \mathrm{~cm}$ compr., inserido na porção mediana ou no terço proximal do pedicelo floral. 3. Schwartzia 


\section{Marcgravia L.}

Hemiepífitas, lianas ou arbustos escandentes; ramos dimórficos, os jovens presos ao substrato por raízes grampiformes, os adultos livres, geralmente decumbentes e lenticelados. Folhas dimórficas, dísticas; as jovens geralmente sésseis, lâmina ovada a ovado-lanceolada, membranácea, base cordada, margem inteira a levemente crenada, ápice obtuso a retuso, geralmente mucronado; as adultas subsésseis ou pecioladas, lâmina elíptica a oblonga, geralmente coriácea, com glândulas geralmente numerosas, base obtusa a cuneada, margem inteira a levemente crenada, ápice agudo ou acuminado. Inflorescência terminal, umbeliforme, às vezes racemosa (grupo Galeatae), geralmente pêndula, com 10-60 flores. Nectários $1-16$, sem flor fértil, inseridos na região central quando inflorescência umbela, cuculados, sacados, saciformes, galeados ou tubulares, sem aurículas na base, pedicelados. Flores pediceladas, com inserção pedicelo-flor reta ou oblíqua; bractéolas opostas ou ausentes; sépalas 4; pétalas 4, conatas em caliptra; estames 7-100, filetes livres, unisseriados ou em várias séries, geralmente heterodínamos; pistilo globoso a cônico, estigma mamilado, subséssil; ovário com 3-20 lóculos. Frutos globosos, septífragos, trivalvares.

Marcgravia possui cerca de 60 espécies distribuídas no sul do México, América Central, Ilhas do Caribe e trópicos da América do Sul (e.g., Picca \& GiraldoCañas 1999; Dressler 2004; Giraldo-Cañas 2007). No Brasil, o gênero está representado por 22 espécies distribuídas principalmente na Amazônia. Na Mata Atlântica, ocorrem quatro espécies (Souza 2012), duas delas registradas na Bahia.

\section{Chave para as espécies}

1. Folhas jovens $2-3,3 \mathrm{~cm}$ larg., as adulta oblongas, com 2 glândulas circulares na base e glândulas diminutas ao longo da margem; flores $12-25$, inserção pedicelo-flor oblíqua; frutos $15-20 \times$ $8-12 \mathrm{~mm}$ 1.1. M. coriacea

1 '. Folhas jovens $0,5-0,7 \mathrm{~cm}$ larg., as adultas elípticas, com 4-8 pares de glândulas elípticas entre a nervura central e a margem da lâmina e numerosas glândulas circulares próximas da margem; flores 50-63, inserção pedicelo-flor reta; frutos $6-10 \times$ $5-8 \mathrm{~mm}$. 1.2. M. polyantha

\subsection{Marcgravia coriacea Vahl, Eclog. Amer. 2: 39.} 1798.

Figuras 1A, 2 e 3.

Hemiepífitas, ca. $15 \mathrm{~m}$ alt.; ramos com lenticelas creme, conspícuas, em série ao longo dos ramos. Folhas jovens com pecíolo 1-2 mm compr.; lâmina $0,7-4,5 \times 2-3,3 \mathrm{~cm}$, ovada, base cordada, margem levemente crenada, ápice obtuso, às vezes mucronado; folhas adultas com pecíolo $2-5 \mathrm{~mm}$ compr., lâmina
6-16,5 × 1,5-5 cm, oblonga, coriácea, com 2 glândulas circulares na base e glândulas diminutas ao longo da margem, base obtusa a truncada, simétrica, margem inteira, levemente revoluta, ápice atenuado. Inflorescência umbeliforme, com 12-25 flores. Nectários 3-5, castanhos, coriáceos, 2,5-4,5 cm compr., sacados ou tubulares, ligeiramente oblíquos, ápice dilatado, abertura circular com borda levemente revoluta; pedicelo 5-15 $\mathrm{mm}$ compr., lenticelado. Flores com inserção pedicelo-flor oblíqua; pedicelo $2-6,5 \mathrm{~cm}$ compr.; bractéola ausente; sépalas $2-3 \times 6-8 \mathrm{~mm}$, ovadas a orbiculares, ápice obtuso a truncado; corola verde com ápice creme, $10-15 \times 6-10 \mathrm{~mm}$, globosa a cônica, ápice obtuso a acuminado; estames 20-23, 6-8 mm compr., conatos na base; pistilo 5-7 $\times$ 3-5 mm compr.; ovário com 7 ou 8 lóculos. Frutos 15-20 × 8-12 mm; epicarpo creme, lenticelado; sementes vermelhas.

América do Sul: Bolívia, Brasil, Colômbia, Equador, Guiana, Peru, Suriname e Venezuela (Giraldo-Canãs 1999; 2002). No Brasil, ocorre na Amazônia e na Mata Atlântica, tendo sido registrada em alguns estados das Regiões Norte, Nordeste, Centro-Oeste e Sudeste (Amorim et al. 2009; Souza 2012). D9, E8, E10, F8, G8, H8 e I8: florestas ombrófilas montanas, submontanas e florestas de restinga. Coletada com flores entre janeiro e abril, junho a agosto e em dezembro, e com frutos em janeiro, março a maio, julho e outubro.

Material selecionado - Arataca, 15'10'27's, 39²0'22”W, 450-800 m, 22 jul. 2005 (fr.), A.M. Amorim et al. 4737 (CEPEC, HUESC, JPB, NY); Conde, 1203'20"S, 37²' $40^{\prime}$ ”W, 18 mar. 1996 (bot.), M.C. Ferreira et al. 892 (HRB, IPA, MBM, RB); Entre Rios, $12^{\circ} 02^{\prime} \mathrm{S}, 31^{\circ} 01^{\prime} \mathrm{W}, 25$ jan. 2012 (est.), A.V. Popovkin et al. 1043 (HUEFS); Ilhéus, 14²5'21'S, 39 ${ }^{\circ} 14^{\prime} 02^{\prime \prime} \mathrm{W}, 10$ dez. 2007 (f1.), R.O. Perdiz et al. 254 (CEPEC, HUEFS); Jaguaripe, 1314'14”S, 3858'42”W, 5 nov. 2011 (fr.), E. Matos \& G. Vital 739 (HUEFS); Santa Cruz Cabrália, 16²'41'S, 3901'29'W, 26 ago. 1994 (bot.), M.L. Guedes et al. 3645 (ALCB, SPF); São Felipe, 12 ${ }^{\circ} 50^{\prime} 50^{\prime \prime}$, 39 395'22”W, fev. 1956 (bot.), R. Lordêlo et al. 56-145 (ALCB); São José da Vitória, $15^{\circ} 05^{\prime} 04^{\prime}$ 'S, 39²0'21'W, 1 maio 2001 (bot.), A.M. Amorim et al. 3646 (CEPEC, NY); Una, 1509'S, 3905'W, 14-15 abr. 1993 (bot.), A.M. Amorim et al. 1250 (CEPEC); Valença, 13²2'13”S, 3904'23”'W, 19 jun. 1973 (bot.), T.S. Santos 2682 (CEPEC).

Marcgravia coriacea pode ser confundida com M. picta Willd., espécie citada para a Bahia por Wittmack (1878) e Souza (2012). Ambas apresentam inflorescência com menos de 25 flores e inserção pedicelo-flor oblíqua, mas $M$. coriacea difere de $M$. picta por apresentar folhas com glândulas circulares na base da lâmina e ao longo da margem (vs. glândulas ausentes), nectário tubular (vs. galeado) e ovário com 7 ou 8 lóculos (vs. 10 a 12 lóculos). Desse modo, os materiais previamente identificados como $M$. picta na Bahia e mencionados nos trabalhos citados acima pertencem, na verdade, a $M$. coriacea. 


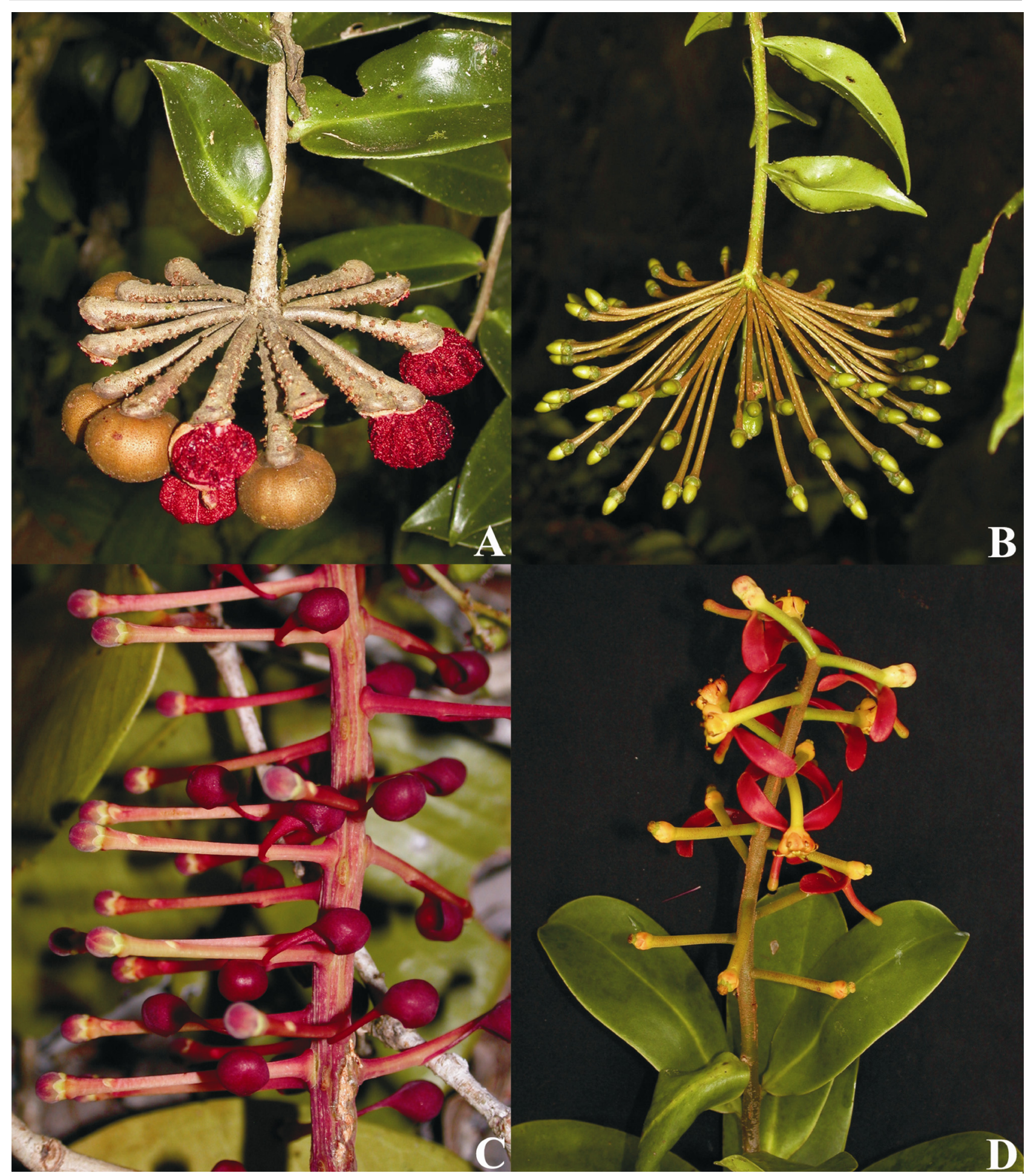

Figura 1. A- Marcgravia coriacea: infrutescência com sementes expostas; B- M. polyantha: inflorescência jovem; C- Schwartzia brasiliensis: botões com nectário pedicelado; D- Souroubea guianensis: ramo com inflorescência (Fotos: A. Amorim).

1.2. Marcgravia polyantha Delpino, Atti Soc. Ital. Sci. Nat. 12: 182, 210. 1869.

Figuras 1B, 4 e 5.

Hemiepífitas, 6-20 m alt.; ramos com lenticelas creme, distribuídas aleatoriamente ao longo do ramos. Folhas jovens sésseis ou com pecíolo até ca. $1 \mathrm{~mm}$ compr., lâmina 7-10 × 5-7 mm, ovada, base cordada, margem levemente crenada, ápice obtuso; folhas adultas com pecíolo ca. $3 \mathrm{~mm}$ compr., lâmina 2,5-9,5 $\times 1,2-3,8 \mathrm{~cm}$, elíptica, coriácea, com $4-8$ pares de glândulas entre a nervura central e a margem da lâmina, elípticas, com numerosas glândulas circulares diminutas próximas da margem, base atenuada a cuneada, simétrica, margem inteira a levemente crenada, pouco revoluta, ápice agudo a acuminado. Inflorescência umbeliforme, com 50-63 flores. Nectários 4-6, verdes com ápice castanho, 2,5-4,3 cm compr., saciformes a tubulares, oblíquos, ápice 


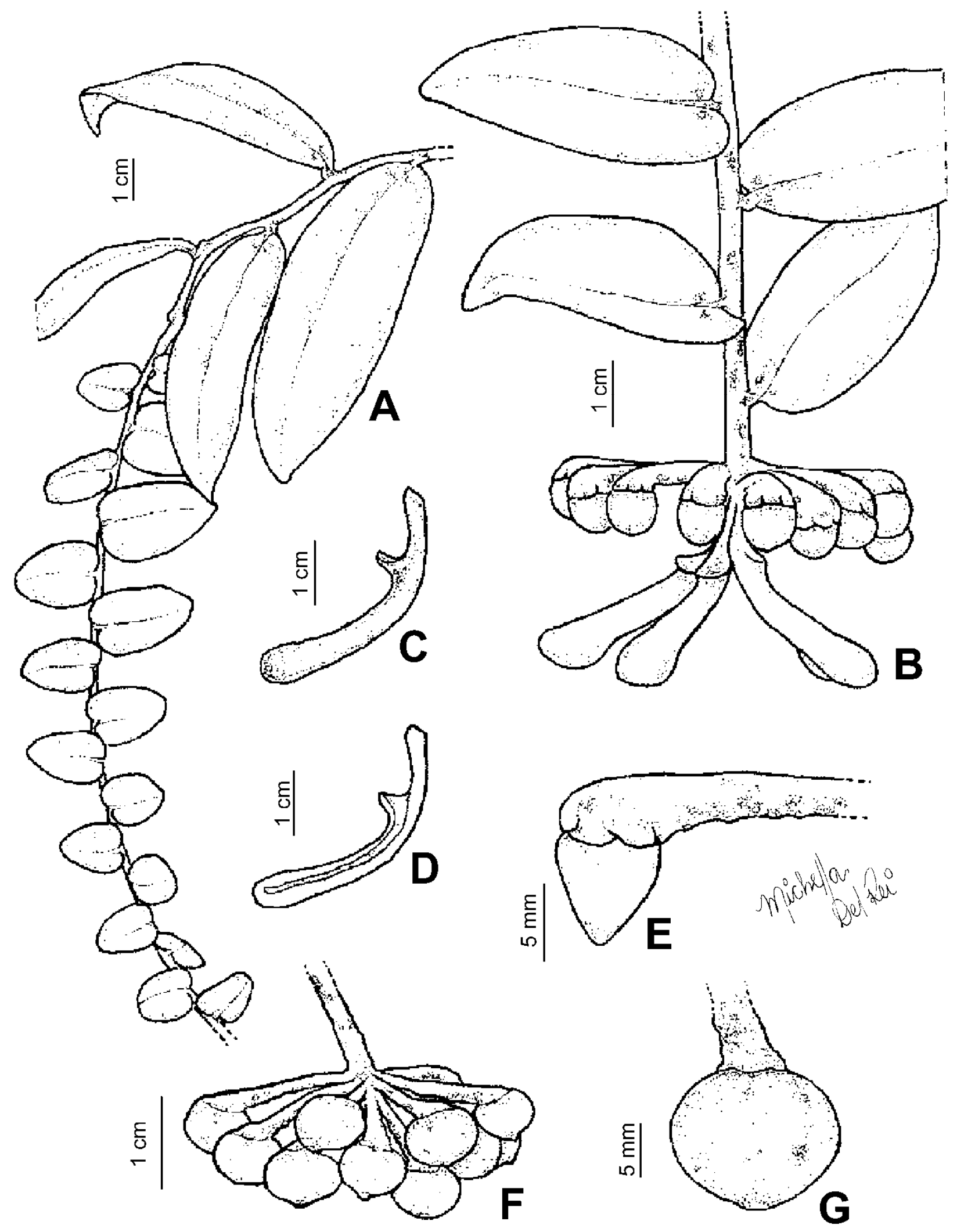

Figura 2. Marcgravia coriacea: A- ramo de plantas jovens e adultas (dimórfico); B- ramo com inflorescência; C- nectário (vista lateral); D- nectário (corte longitudinal); E- botão; F- infrutescência; G- fruto. (A e E- Amorim 1250; B-D e F-G- Amorim 4737). 


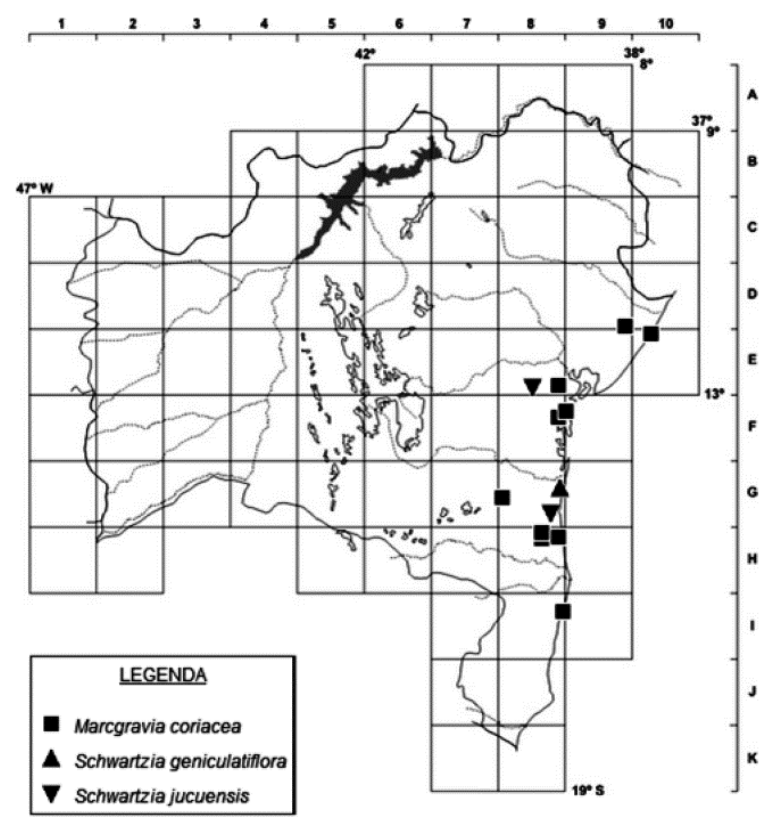

Figura 3. Distribuição geográfica de Marcgravia coriacea, Schwartzia geniculatiflora e $S$. jucuensis no estado da Bahia.

dilatado, abertura circular com apêndice dorsal involuto; pedicelo $1-1,5 \mathrm{~cm}$ compr., lenticelado. Flores com inserção pedicelo-flor reta; pedicelo 3,5-7 cm compr.; bractéolas $2-3 \times$ ca. $3 \mathrm{~mm}$; sépalas $2-3 \times 3-5 \mathrm{~mm}$ compr., orbiculares, ápice obtuso; corola verde, $1-1,2 \mathrm{~cm} \times 4-5 \mathrm{~mm}$ compr., cilíndrica a cônica, ápice obtuso; estames $25-27,3-8 \mathrm{~mm}$ compr., conatos na base; pistilo ca. $5 \mathrm{~mm}$ compr.; ovário com 6-8 lóculos. Frutos 6-10 × 5-8 mm compr.; epicarpo creme, densamente lenticelado; sementes vermelhas.

Endêmica do Brasil, ocorrendo em todos os estados das Regiões Sudeste e Sul (Souza 2012). G8, H8 e I8: florestas ombrófilas montanas e submontanas. Coletada com flores entre junho e setembro e de novembro a dezembro, e com frutos em novembro e dezembro.

Material selecionado - Arataca, 15\%10'27'S, 39'20'22”'W, 21 jul. 2005, J.G. Jardim et al. 4697 (CEPEC, HUEFS, NY, RB); Barro Preto, 1446'13"S, 39³2'10"W, 2 nov. 2003 (bot. e fl.), P. Fiaschi et al. 1772 (CEPEC, SPF); Camacan, 15'23'29'S, 39³3'55'W, 21 set. 2004 (bot.), W.W. Thomas et al. 14217 (CEPEC); Eunápolis, 16²2’39’S, 39³4'49”W, 2 jul. 1970 (bot.), T.S. Santos 866 (CEPEC); Ilhéus, 14³5'10”S, 3907’25”W, 170 m, 19 dez. 2004 (bot. e fr.), A.M.A. Amorim et al. 4552 (CEPEC).

Ao analisar a descrição original de Marcgravia polyantha (Delpino 1869) observou-se sobreposição dos caracteres diagnósticos da espécie com os dos espécimes utilizados neste estudo, como forma da folha, número e disposição das glândulas na face abaxial da lâmina e forma da flor e do nectário. No entanto, os materiais aqui citados como $M$. polyantha apresentaram algumas diferenças marcantes em relação à obra princeps, principalmente o tamanho do nectário, que variou de 2,5 a 4,5 cm compr. (vs. 0,7-1,8 cm compr.), e o número de flores por inflorescência, que variou de 50 a 63 (vs. 20-40). Além disso, a distribuição geográfica dos materiais aqui incluídos é restrita ao sul da Bahia, enquanto os demais materiais são provenientes do Distrito Federal e das Regiões Sudeste e Sul do Brasil (Souza 2012).

Os espécimes de Marcgravia polyantha coletados na Bahia já haviam sido identificados como $M$. myriostigma Triana \& Planch. devido à presença de inflorescências com mais de 50 flores e 4 a 6 nectários, além das flores com inserção reta no pedicelo e 25 a 30 estames. Entretanto, M. polyantha diferencia-se de M. myriostigma principalmente por possuir folhas adultas com lâmina elíptica (vs. ovado-lanceolada), com base simétrica (vs. levemente assimétrica), e glândulas de distribuição em série entre a nervura central e a margem (vs. glândulas distribuídas aleatoriamente ao longo da lâmina). Além disso, M. myriostigma é conhecida apenas do Departamento de Chocó, na Colômbia (Giraldo-Cañas 2002), ao passo que $M$. polyantha possui distribuição restrita ao leste do Brasil.

\section{Norantea Aubl.}

Arbustos escandentes ou hemiepífitos, raro arvoretas, terrestres ou rupícolas; ramos monomórficos, eretos a decumbentes. Folhas espiraladas; subsésseis ou pecioladas; lâmina coriácea, raro membranácea, ovada, oblongo-lanceolada, oblongo-obovada ou obovada, com até 6 pares de glândulas com distribuição irregular na face abaxial, base subcordada a cuneada, margem inteira, ápice retuso, emarginado ou mucronado. Inflorescência terminal, racemosa, ereta, com mais de 80 flores. Nectários $>2,5 \mathrm{~cm}$ compr., com flor fértil, inseridos da porção mediana ao terço distal do pedicelo floral, tubulares, obovados, saciformes, cilíndricos, cuculiformes ou galeados, sem aurículas na base, sésseis ou pedicelados. Flores com inserção pediceloflor reta; pedicelo geralmente $<1 \mathrm{~cm}$ compr.; bractéola oposta ou subposta; sépalas 5 , livres ou conatas na base; pétalas 5, livres; estames $15-38$, livres, pistilo ovado, piriforme a cônico, estigma mamiforme, séssil; ovário com (3)4 ou 5(6) lóculos. Frutos globosos ou cônicos, geralmente apiculados.

Norantea possui duas espécies, distribuídas na América Central (Costa Rica), Trinidad e Tobago e na América do Sul (Ferreira 1995; Giraldo-Cañas 2007). No Brasil, está representado por $N$. guianensis, com ocorrência ampla no Cerrado e na Amazônia, ocorrendo em toda a Região Norte e Nordeste e em alguns estados das Regiões Centro-Oeste e Sudeste (Souza 2012). O gênero é citado pela primeira vez para a Bahia.

2.1. Norantea guianensis Aubl., Pl. Gui. 1: 554, t. 220. 1775.

Figuras 6A-E e 7.

Nome popular: Canudo (Miranda 3000).

Arbustos escandentes ou hemiepífitos, 2,5-7 m alt.; ramos marrons, raízes ao longo dos ramos. Folhas com 

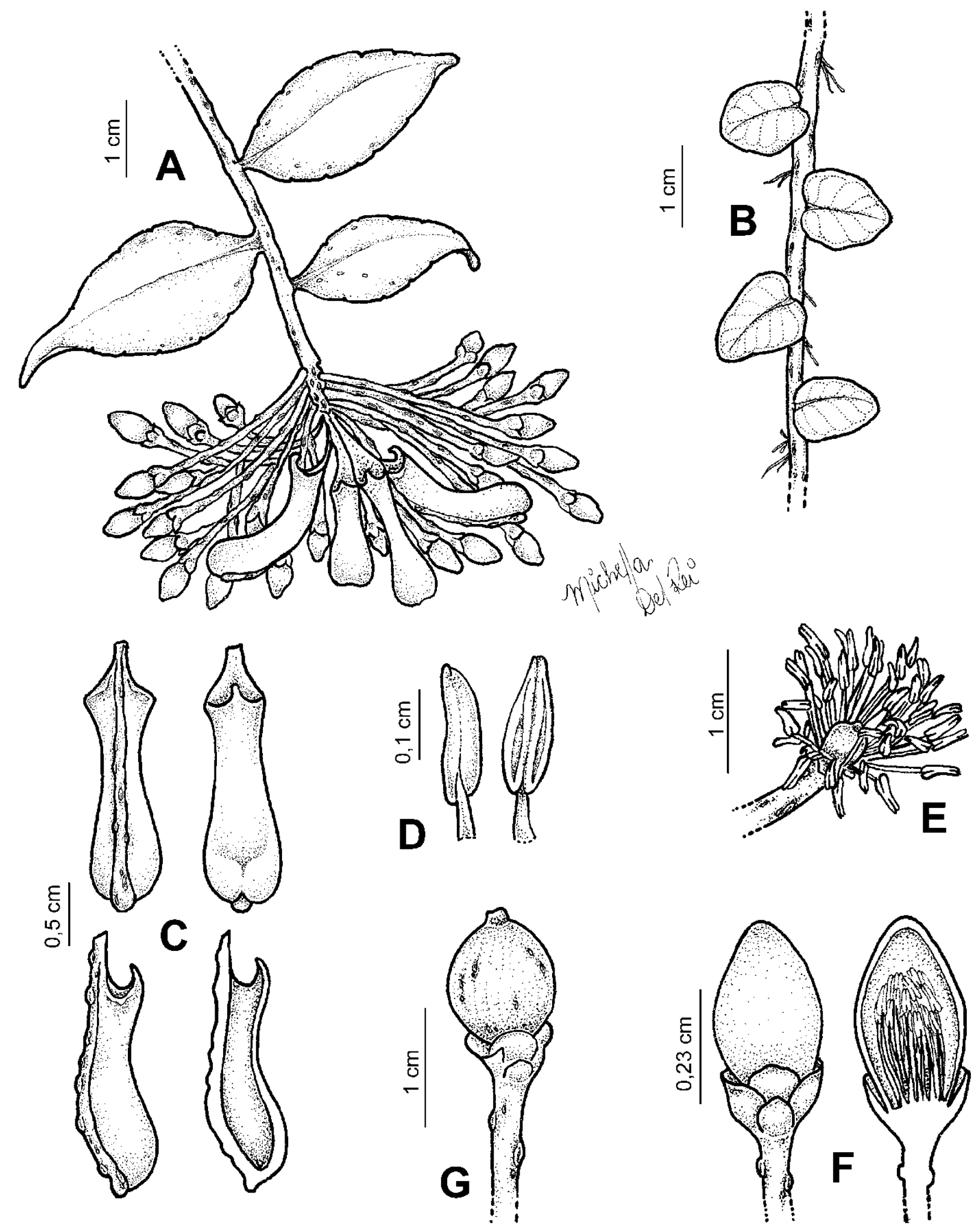

Figura 4. Marcgravia polyantha: A- ramo com inflorescência; B- ramo da planta jovem; C- nectário em vista adaxial (esquerda) e vista abaxial (direita); D- nectário em vista lateral (esquerda) e corte longitudinal (direita); E- botão floral e detalhe em corte longitudinal (direita); F- flor em antese; G- ápice do estame em vista adaxial (esquerda) e abaxial (direita); H- fruto. (A, C-H- Fiaschi 1772; B- Amorim 4250). 


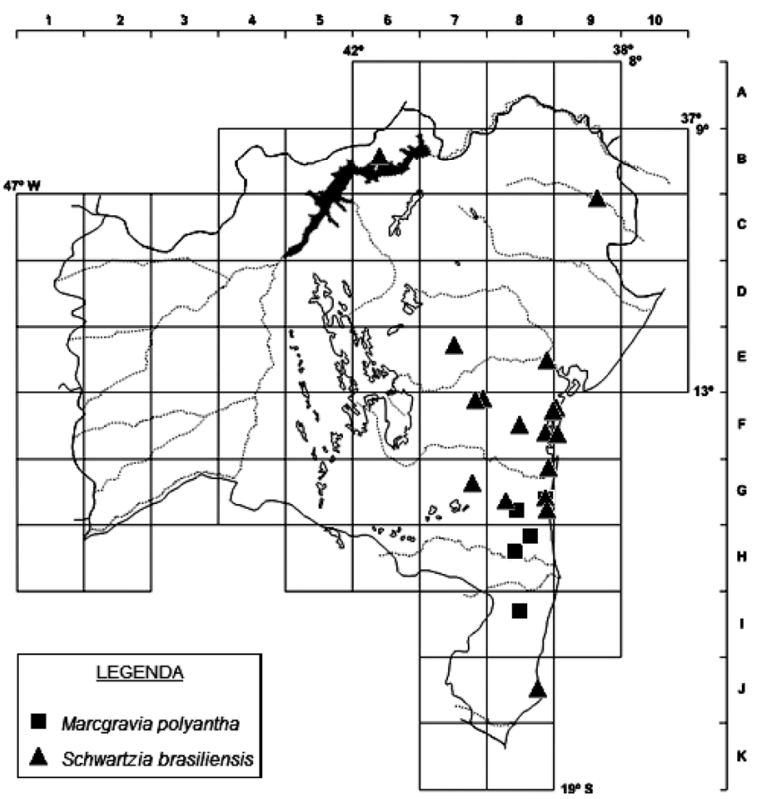

Figura 5. Distribuição geográfica de Marcgravia polyantha e Schwartzia brasiliensis no estado da Bahia.

pecíolo ca. $3 \mathrm{~cm}$ compr.; lâmina $8-21 \times 3-8,5 \mathrm{~cm}$, oblongo-obovada a mais comumente obovada, coriácea, com 3-6 pares de glândulas orbiculares a ovadas, distribuídas irregularmente na superfície abaxial, base cuneada, margem inteira, ápice retuso, emarginado ou mucronado. Inflorescência com 110-150 flores; raque 22-48 cm compr. Nectários vermelhos, brilhantes, membranáceos, 2,5-5 cm compr., tubulares a saciformes, abertura oblonga a elíptica; pedicelo 0,5-2 cm compr. Flores com inserção pedicelo-flor reta; pedicelo 0,3-1 cm compr.; bractéolas ca. $1 \times 1 \mathrm{~mm}$; sépalas ca. $2 \times 2 \mathrm{~mm}$, ovadas a orbiculares; pétalas 4-6 × 3-5 mm, ovadas a orbiculares, rosa ou vináceas; estames 15 , adnatos à base das pétalas; pistilo ca. 0,15 mm compr., piriforme a cônico; ovário com 5 lóculos. Frutos imaturos $6-8 \times$ 5-8 mm, globosos, apiculados; epicarpo verde; sementes não observadas.

Distribuída da Costa Rica até a Bolívia e o Brasil, sendo encontrada também em algumas Ilhas do Caribe (Ferreira 1995; Giraldo-Cañas 2007, 2011). C5: caatinga arbórea, sobre solo arenoso. Floresce em março, setembro, novembro e dezembro.

Material selecionado - Pilão Arcado, $10^{\circ} 07^{\prime} 48^{\prime \prime S}$, 4253’32”W, 12 ago. 1998 (bot.), A.M. Miranda et al. 3000 (HUEFS, IPA).

Norantea guianensis pode ser confundida com Schwartzia brasiliensis, diferindo desta por apresentar pedicelos mais curtos (0,3-1 vs 1,5-3 cm compr.) e nectários mais longos (2,5-5 vs. 0,6-1 cm compr.), tubulares a saciformes (vs. cocleariforme). Seus ramos são usados para fazer flechas para caçar peixes, e as flores são visitadas por abelhas (arapuá) e borboletas (Miranda 3000, in sched.).
3. Schwartzia Vell.

Arbustos escandentes ou lianas, rupícolas ou terrestres; ramos monomórficos, geralmente estriados. Folhas espiraladas; sésseis ou pecioladas; lâmina coriácea, ovada a obovada, glândulas geralmente numerosas, principalmente próximas da margem foliar; base obtusa a cuneada, margem inteira, levemente revoluta, ápice obtuso, retuso a emarginado, mucronado. Inflorescência terminal, raro lateral, racemosa, geralmente densa, ereta, com 8-160 flores. Nectários $<2 \mathrm{~cm}$ compr., com flor fértil, inseridos da porção mediana ao terço proximal do pedicelo floral, saciformes, tubulares, cocleariformes ou galeados, sem aurículas na base, pedicelados. Flores com inserção pedicelo-flor reta ou oblíqua; pedicelos $>1,5 \mathrm{~cm}$ compr.; bractéolas alternas, subpostas ou opostas; sépalas 5, livres ou conatas na base; pétalas 5 , livres ou conatas na base; estames 10 a numerosos, livres ou basalmente conatos e/ou adnatos às pétalas; pistilo globoso, cônico a piriforme, estigma mamiforme; ovário com 3-5 lóculos. Frutos globosos, ápice acuminado, geralmente apiculado.

Schwartzia possui 16 espécies, da Costa Rica à Bolívia e sul do Brasil (Giraldo-Cañas 2001a,b,c, 2003, 2004). No Brasil, o gênero está representado por quatro espécies, que se distribuem em todos os Estados da Região Sudeste e alguns das Regiões Nordeste, CentroOeste e Sul, sendo encontrado no Cerrado e na Mata Atlântica (Souza 2012). As quatro espécies que ocorrem no Brasil estão representadas na Bahia.

\section{Chave para as espécies}

1. Flores com inserção pedicelo-flor oblíqua.

2. Folhas com 8-12 pares de glândulas paralelas entre a nervura central e a margem da lâmina, pecíolo até ca. $3 \mathrm{~mm}$ compr.; inflorescência $12-$ 18 cm compr., com 20-68 flores, nectários saciformes a tubulares, pedicelados.

3.1. S. adamantium

2'. Folhas com 1-4 pares de glândulas próximas da margem da lâmina, pecíolo ca. $8 \mathrm{~mm}$ compr.; inflorescência ca. $6 \mathrm{~cm}$ compr., com 8-10 flores, nectários galeados, sésseis

3.3. S. geniculatiflora

1'. Flores com inserção pedicelo-flor reta.

3. Folhas com 3-6 pares de glândulas próximas da margem e 1 par de glândulas na base da lâmina; inflorescência 21-32 cm compr., com 40-83 flores, nectários cocleariformes ..

3.2. S. brasiliensis

3'. Folhas com 1-4 pares de glândulas próximas da margem; inflorescência 2,5-10 cm compr., com 18-22 flores, nectários saciforme-tubulares 


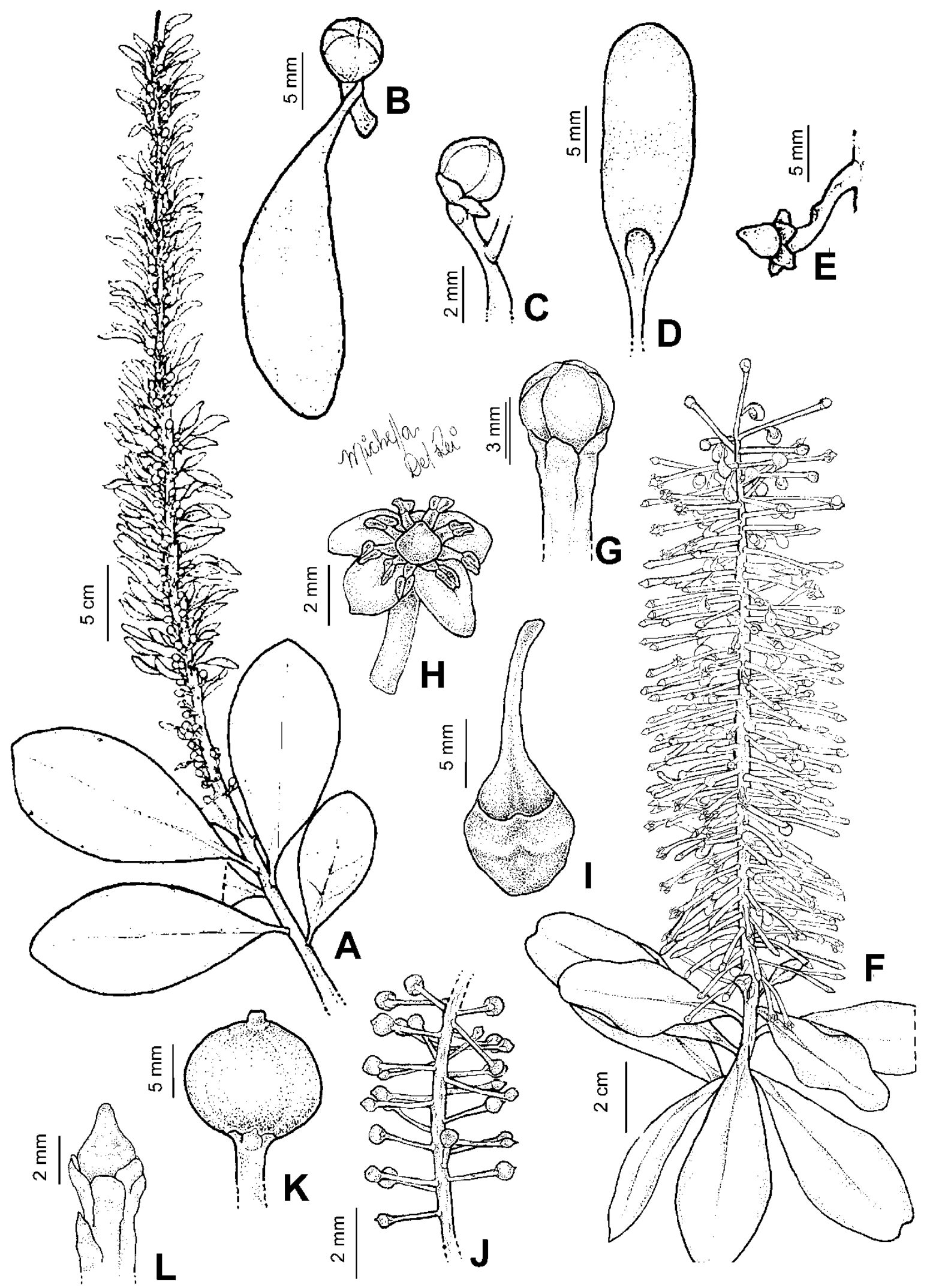

Figura 6. A-E. Norantea guianensis: A- ramo com inflorescência; B- botão floral associado ao nectário; C- botão floral; D- nectário; E- fruto imaturo. F-L. Schwartzia brasiliensis: F- ramo com inflorescência; G- botão floral; H- flor; I- nectário; J- parte da infrutescência; K- fruto maduro; L- fruto imaturo (A-D- Queiroz 10906; E- Souza 1584; F-I, L- Lopes 453; J-K- França 911 ). 
3.1. Schwartzia adamantium (Cambess.) Bedell ex Giraldo-Cañas, Hickenia 3(32): 121. 2002.

Figuras 7 e 8.

Arbustos escandentes, ca. $3 \mathrm{~m}$ alt., rupícolas ou terrestres; ramos acinzentados, estriados. Folhas sésseis ou com pecíolo até ca. $3 \mathrm{~mm}$ compr., levemente estriado; lâmina 6-10 × 3-7 cm, ovada a obovada, coriácea, base cuneada, ápice obtuso ou levemente emarginado, com 8-12 pares de glândulas, elípticas a circulares, paralelas entre a nervura central e a margem da lâmina. Inflorescência com 20-68 flores; raque 12-18 cm compr. Nectários verdes passando a castanhos, coriáceos, $1-2 \mathrm{~cm} \times 2-8 \mathrm{~mm}$, inseridos no terço proximal do pedicelo, saciformes a tubulares, abertura circular; pedicelo 1-6 mm compr. Flores com inserção pedicelo-flor oblíqua; pedicelo 4-8,5 cm compr.; bractéolas $1-2 \times 2-3 \mathrm{~mm}$; sépalas $2-5 \times 2,5-5 \mathrm{~mm}$, orbiculares, esverdeadas; pétalas 5-9 $\times 3-7 \mathrm{~mm}$, oblongas a obovadas, esverdeadas, levemente vináceas na face abaxial; estames ca. 20, 3-4 mm compr., livres, antera alva a amarela; pistilo $4-5 \mathrm{~mm}$ compr., globosocônico, verde. Frutos 1-1,2 × 1-1,4 cm; epicarpo imaturo verde; sementes vermelhas.

Schwartzia adamantium é endêmica do Brasil, ocorrendo em alguns estados das Regiões Nordeste (Bahia), Centro-Oeste e Sudeste (e.g., Stannard 1995; Peixoto 1985; Sano \& Pirani 2004; Souza 2012). E2, E3, F5 e F6: cerrados e campos rupestres. Floresce de junho a agosto e de outubro a dezembro e frutifica de julho a setembro e em dezembro.

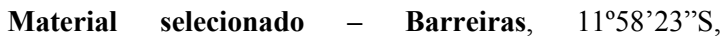
45³0'53”'W, 744 m, 14 nov. 2012 (fr.), R.F. Monteiro et al. 627

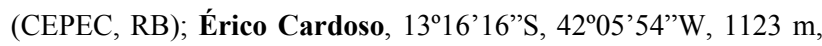
4 jul. 2001 (bot. e fl.), T. Ribeiro 341 (ALCB, CEPEC, HRB, HUEFS, HUESC); Oliveira dos Brejinhos, 12'22'53"S,

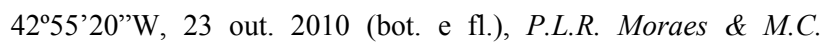

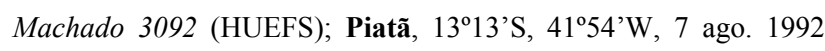
(bot. e fl.), W. Ganev 811 (HUEFS); Rio de Contas, $1^{\circ} 32^{\prime}$ 'S, 41 ${ }^{\circ} 54^{\prime} \mathrm{W}, 1180-1200 \mathrm{~m}, 28$ out. 1988 (bot.), R.M. Harley et al. 25726 (CEPEC, MBM, RB); São Desidério, 5 out. 2007, $M$. Oliveira et al. 3048 (EAC, HVASF).

Schwartzia adamantium pode ser confundida com S. brasiliensis, diferenciando-se pelos nectários saciformes a tubulares (vs. cocleariformes) e pedicelos florais maiores ( $4-8,5$ vs. até $3 \mathrm{~cm}$ compr.)

\subsection{Schwartzia brasiliensis (Choisy) Bedell ex Gir.-}

Cañas, Caldasia 23: 341. 2001.

Figuras $1 \mathrm{C}, 5$ e $6 \mathrm{~F}-\mathrm{L}$.

Nome popular: Ararrapé (Grupo Pedra do Cavalo 1000).

Arbustos escandentes, 6-25 m alt., terrestres; ramos lisos a levemente estriados. Folhas com pecíolo ca. 1,5 cm compr.; lâmina 7-10 × 4-6 cm, obovada, coriácea, base obtusa a cuneada, ápice obtuso, com 3-6 pares de glândulas próximas da margem e 1 par de glândulas na base da lâmina. Inflorescência com
40-83 flores; raque 21-32 cm compr. Nectários vináceos a roxos, $6-10 \times 4-7 \mathrm{~mm}$, inseridos no terço proximal do pedicelo, cocleariformes, abertura circular com borda levemente revoluta; pedicelo 3-6 $\mathrm{mm}$ compr. Flores com inserção pedicelo-flor reta; pedicelo 1,5-3 cm compr.; bractéolas ca. $1 \times 1 \mathrm{~mm}$ compr., subpostas; sépalas $1-2 \times$ ca. $1 \mathrm{~mm}$, orbiculares, amarelo-esverdeadas; pétalas 4-6 $\times$ 3-5 $\mathrm{mm}$, obovadas, púrpura a vináceas, ápice obtuso a levemente retuso; estames 14, ca. 1,5 mm compr., adnatos às pétalas, antera vinácea ou amarelada; pistilo ca. 1,5 mm compr.; ovário com 4 ou 5 lóculos. Frutos $8-12 \times 9-13 \mathrm{~mm}$; epicarpo imaturo verde; sementes não observadas.

Endêmica do Brasil, ocorrendo das Regiões Nordeste a Sul, chegando ao Centro-Oeste (e.g., Reitz 1968; Peixoto 1985; Giraldo-Cañas \& Fiaschi 2005; Souza 2012). B6, C9, E7, E8, F7, F8, F9, G8 e J8: campo rupestre, caatinga arbórea, florestas ombrófilas submontanas, florestas ciliares e restingas. Floresce de outubro a janeiro e frutifica de janeiro a março.

Material selecionado - Alcobaça, $17^{\circ} 30^{\prime}$ S, 39 $9^{\circ} 13^{\prime} \mathrm{W}, 15$ jan. 1977 (bot.), R.M. Harley et al. 17940 (CEPEC, IPA); Almadina, 14'38'27'S, 3942'47'W, 12 mar. 2005, P. Fiaschi et al. 2755 (CEPEC); Cachoeira, 12³7'06”'S, 3857'21'W, dez. 1980 (bot.), Grupo Pedra do Cavalo 1000 (ALCB, CEPEC, EAC, HRB, IPA,

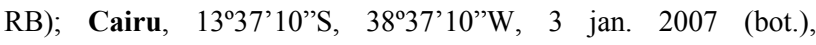

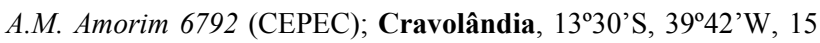
jan. 1994 (fr.), F. França et al. 911 (HUEFS, RB); Guaibim, 13¹7'16”S, 3859'45”W, 1 maio 1980 (fl.), A.P. Araújo 295 (HRB); Ilhéus, 14\%4'20”S, 3902'58”W, 20 set. 2007 (fl.), M.M.M. Lopes et al. 1585 (CEPEC); Itajuípe, 1440’41”S, 39 $22^{\prime} 30^{\prime \prime} \mathrm{W}, 18$ nov. 1971 (bot.), T.S. Santos 2186 (CEPEC); Jeremoabo, 1004'30”S, 38²8'51'W, dez. 1985 (bot.),

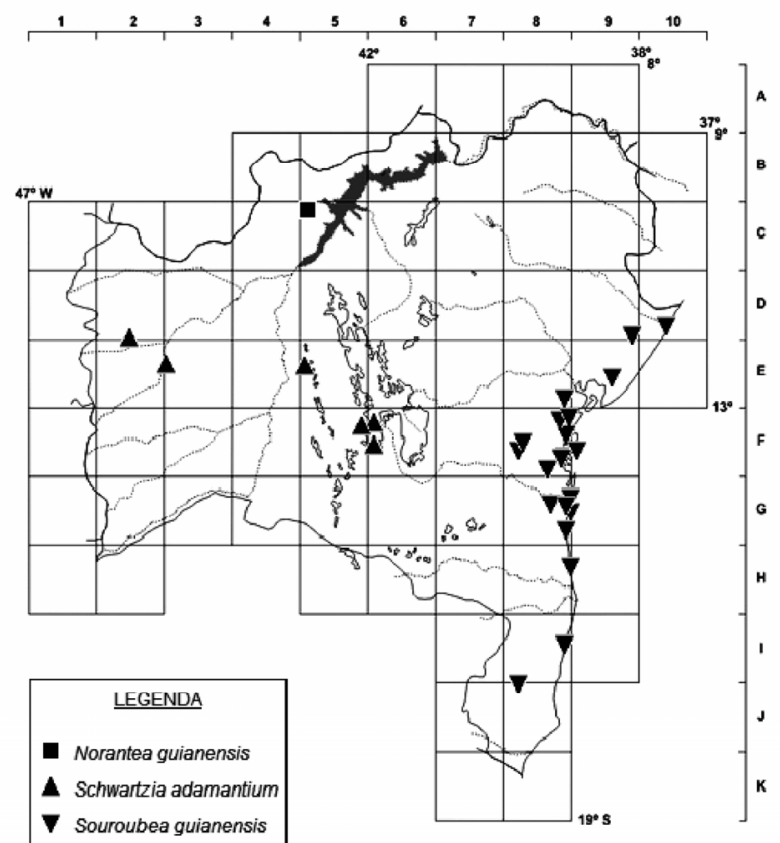

Figura 7. Distribuição geográfica de Norantea guianensis, Schwartzia adamantium e Souroubea guianensis no estado da Bahia. 


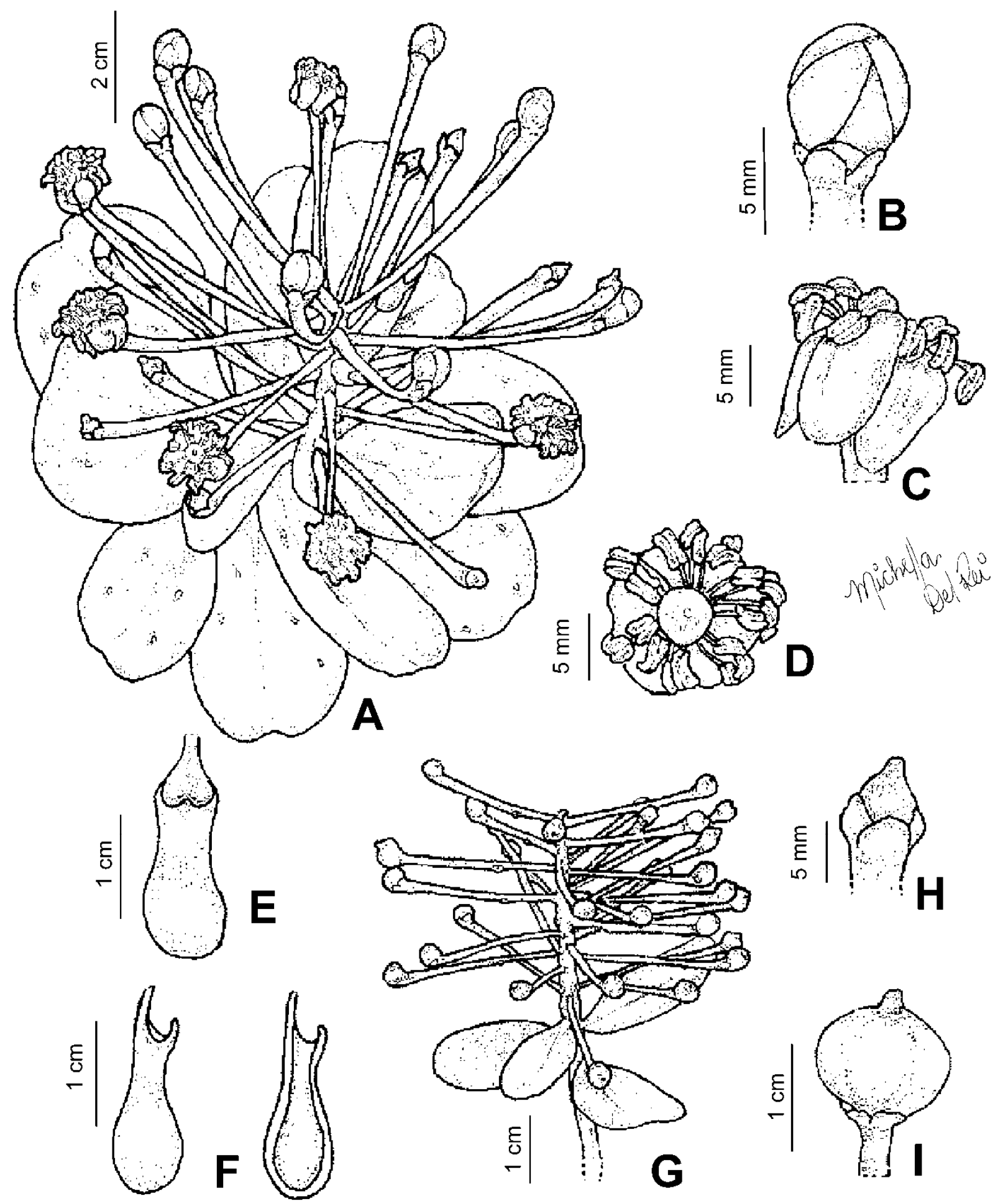

Figura 8. Schwartzia adamantium: A- ramo com inflorescência; B- botão floral; C- flor; D- flor em vista adaxial; E- nectário em vista abaxial (acima); F- nectário em vista lateral (esquerda) e em corte transversal (direita); G- ramo com infrutescência; H- fruto imaturo; I- fruto maduro (A-F- Ribeiro 341; G-I- Harley 26538).

M.L. Guedes 1009 (ALCB); Maracás, 1326'28”'S, 40²5’51'W, 15 fev. 1979 (fr.), T.S. Santos et al. 3481 (CEPEC, RB); Nilo Peçanha, 13³5'58'S, 3906’25”'W, fev.1952 (fl.), G.C.P. Pinto et al. 52-28 (ALCB); Paulo Afonso, 09³3'08”S, 38³0'47’W, 31 jan. 2006 (fr.), M.M.M. Lopes et al. 453 (CEPEC, HUEFS); Planaltino, 1306'54”'S, 4009'50"W, 7 dez. 2000 (bot.), B.M. Silva et al. 117 (CEPEC, HUEFS); Rui Barbosa, 12¹8'09”'S, 40²9'16”'W, 17 jan.
2006 (bot.), L.P. Queiroz \& D. Cardoso 12053 (HUEFS); Valença, 1322'13”S, 3904'23”W, fev. 1968 (fr.), G.C.P. Pinto 8969 (ALCB).

Schwartzia brasiliensis pode ser confundida com S. adamantium e S. jucuensis, diferenciando-se delas principalmente pela presença de nectário cocleariforme (Figura 6I), enquanto S. adamantium e S. jucuensis possuem nectários saciformes a tubulares. 
3.3. Schwartzia geniculatiflora Gir.-Cañas \& Fiaschi, Caldasia 27(2): 185. 2005.

Figuras 3 e 9 A-C.

Arbustos escandentes, terrestres; ramos estriados longitudinalmente. Folhas com pecíolo ca. $8 \mathrm{~mm}$ compr., levemente estriado; lâmina 5-8 × 2,5-3,5 cm, obovada, coriácea, base arredondada, levemente assimétrica, ápice obtuso, mucronado, com 1-4 pares de glândulas elípticas próximas da margem da lâmina. Inflorescência com 8-10 flores; raque ca. $6 \mathrm{~cm}$ compr. Nectários ca. $5 \times 4 \mathrm{~mm}$, inseridos no terço proximal do pedicelo, galeados, abertura elipsoide, sésseis. Flores com inserção pedicelo-flor oblíqua; pedicelo 1,7-2 cm compr.; bractéolas $2-2,5 \times$ ca. $2 \mathrm{~mm}$; sépalas 2-3 mm compr., orbiculares; pétalas ca. $5 \times 4 \mathrm{~mm}$ compr., ovadas; estames 18 , ca. $5 \mathrm{~mm}$ compr., livres; pistilo ca. $3 \mathrm{~mm}$ compr., cônico, lóculos não observados. Frutos ca. 1,3 × $1 \mathrm{~cm}$, apiculados; epicarpo verde; sementes não observadas.

Endêmica da Bahia, restrita à Mata Atlântica. G8: floresta ombrófila submontana. Coletada com flores e frutos em novembro.

Material examinado - Uruçuca, 1425'24'S, 3903'38”W, 15 nov. 1995 (bot. e fr.), W.W. Thomas et al. 11029 (isótipos CEPEC, MBM).

Schwartzia geniculatiflora pode ser facilmente reconhecida pelos nectários sésseis, galeados, e pela posição oblíqua da flor em relação ao pedicelo, uma característica pouco comum neste gênero (GiraldoCañas \& Fiaschi 2005).

\subsection{Schwartzia jucuensis Gir.-Cañas, Darwiniana 42:} 173. 2004.

Figuras 3 e 9D-H.

Arbustos escandentes, ca. $4 \mathrm{~m}$ alt., terrestres; ramos levemente estriados. Folhas com pecíolo 1,3-2 cm compr.; lâmina 6,5-8 × 3,7-4,2 cm, elíptica a obovada, coriácea, base cuneada, revoluta, ápice obtuso a retuso, com 1-4 pares de glândulas circulares próximas da margem. Inflorescência curta e densa, com 18-22 flores; raque 2,5-10 cm compr., estriada. Nectários verdes, $0,7-1 \mathrm{~cm}$ compr., inseridos no terço proximal do pedicelo, saciformes a tubulares, ápice dilatado, abertura circular; pedicelo 3-5 mm compr. Flores com inserção pedicelo-flor reta; pedicelo 3,8-4,8 cm compr.; bractéolas ca. $1,8 \times 1,5 \mathrm{~mm}$; sépalas verdes, ca. $1 \times 2 \mathrm{~mm}$, suborbiculares, ápice obtuso; pétalas verdes, 4,8-5,2 mm compr., oblongas, ápice mucronado; estames 15, ca. $3 \mathrm{~mm}$ compr., adnatos à base das pétalas; pistilo ca. $3 \times 1,5 \mathrm{~mm}$, cônico, levemente estriado longitudinalmente; lóculos não observados. Frutos imaturos ca. 1,3 × 1,2 cm, ápice acuminado; epicarpo verde, passando a vináceo; sementes não observadas.

Endêmica do Brasil, ocorrendo nos estados da Bahia e Espírito Santo (Giraldo-Cañas 2004; GiraldoCañas \& Fiaschi 2005; Amorim et al. 2009; Souza 2012). E8 e G8: florestas ombrófilas montanas. Floresce em novembro e frutifica em janeiro.
Material selecionado - Barro Preto, 14\%46'13"S, 39³2'10"W, 2 nov. 2003 (bot.), P. Fiaschi et al. 1850 (CEPEC, SPF); Elísio Medrado, 1252'10”'S, 39²8'18”W, 4 dez. 2004 (fl.), J. Jardim et al. 4308 (HUEFS).

Material adicinional - BRASIL. Espírito Santo. Domingos Martins, 8 nov. 1993 (bot.), G. Hatschbach et al. 59728 (isótipos CEPEC, MBM).

Schwartzia jucuensis pode ser confundida com S. adamantium na fase jovem devido à semelhança dos nectários. Entretanto, esta espécie é a única do gênero no estado que possui uma inflorescência curta e densa. Outra característica diagnóstica importante de $S$. jucuensis é o pecíolo relativamente longo (1,3-2 cm compr.) quando comparado ao de outras espécies do gênero.

\section{Souroubea Aubl.}

Arbustos escandentes ou lianas; ramos monomórficos, geralmente lenticelados. Folhas espiraladas; pecioladas; lâmina coriácea, obovada, oblonga, elíptica a levemente lanceolada, geralmente assimétrica, glândulas geralmente numerosas, próximas da margem, base atenuada a cuneada, margem inteira, ápice obtuso, arredondado ou mucronado. Inflorescência terminal, racemosa, ereta, com 8-60(-100) flores. Nectários com flor fértil, inseridos no ápice do pedicelo floral, logo abaixo do cálice, tubulares a saciformes, base biauricular, subconvexa, sésseis. Flores com inserção pedicelo-flor reta; bractéolas opostas; sépalas 5 , livres ou conatas na base; pétalas (3-)5(6), conatas na base; estames 3 ou 5, geralmente alternos às pétalas, livres ou adnatos às pétalas; pistilo oval a pentagonal, estigma subséssil, subpentágono cônico, sulcado; ovário com 3-5 lóculos. Frutos globosos a subglobosos, apiculados.

Souroubea ocorre do México até a Bolívia, incluindo o Brasil, e contém ca. 20 espécies (Machado \& Lopes 2000; Giraldo-Cañas 2007). No Brasil, está representado por cinco espécies e três subespécies distribuídas nas Regiões Norte, Nordeste e Sudeste (Souza 2012). Na Bahia, ocorre apenas Souroubea guianensis.

\subsection{Souroubea guianensis Aubl., Hist. P1. Guiane 1:} 554; t. 220. 1775.

Figuras 1D, 7 e 10.

Arbustos escandentes, 3-5 $\mathrm{m}$ alt; ramos lenticelados. Folhas com pecíolo 5-10 mm compr.; lâmina 5,1-11 × 2,5-5 cm, obovada a oblonga, base atenuada a cuneada, margem inteira, ápice obtuso ou mucronado, com 8-10 pares de glândulas elípticas próximas da margem e 2 glândulas circulares na base da lâmina. Inflorescência com 20-28 flores; raque 15-18 cm compr. Nectários vermelhos, coriáceos, 2-3 cm compr., tubulares, ápice dilatado, aurículas 1,5-2 cm compr. Flores com pedicelo ca. 2,5 cm compr., com lenticelas em série; bractéolas 3-5 × 3,5-5 mm, ovadas a orbiculares, acuminadas; sépalas $2-3 \times 4-5 \mathrm{~cm}$ 


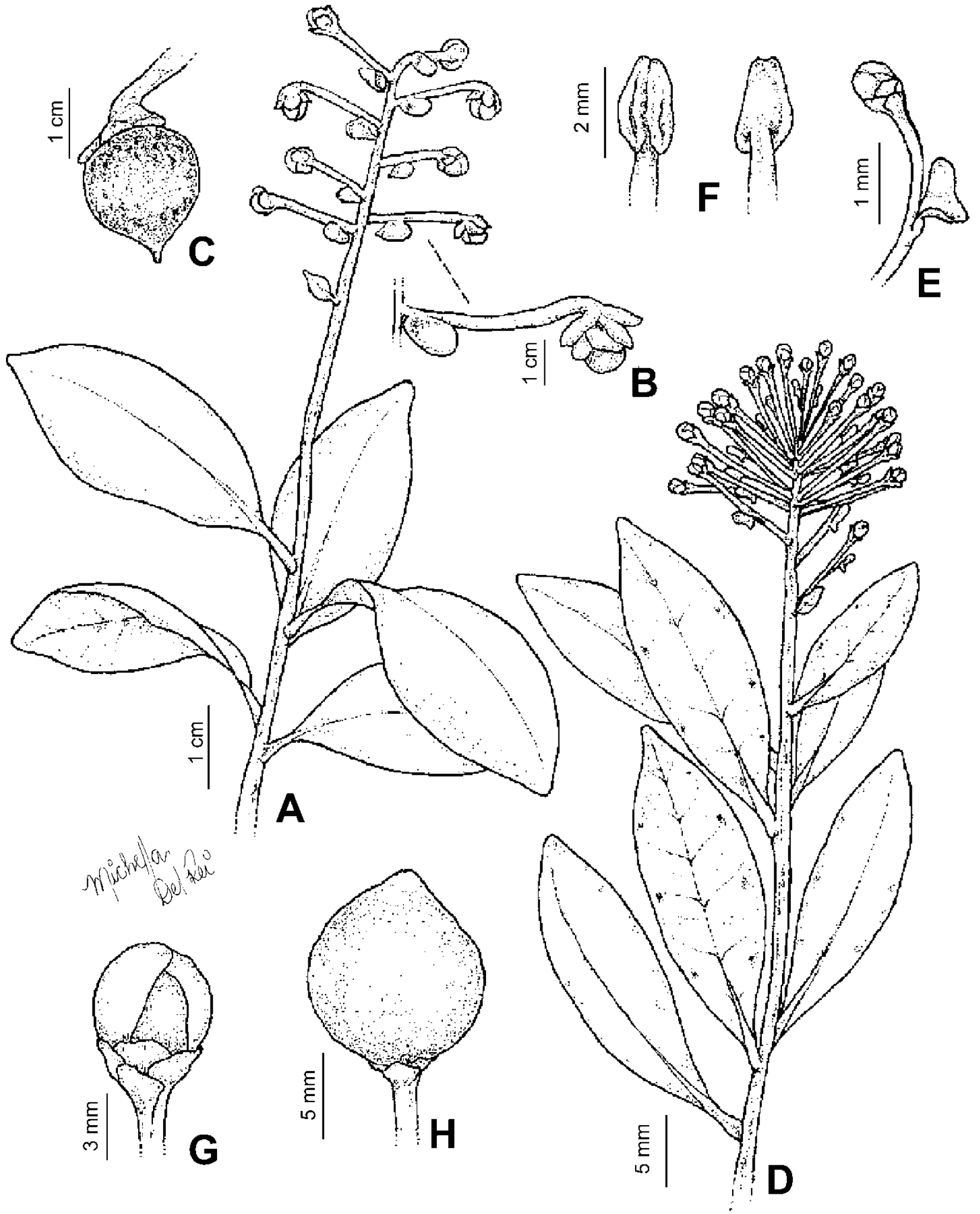

Figura 9. A-C. Schwartzia geniculatiflora: A- ramo com inflorescência; B- botão floral associado ao nectário; C- fruto maduro. D-H. S. jucuensis: D- ramo com inflorescência; E- botão floral associado ao nectário; F- ápice do estame em vista abaxial (direita) e adaxial (esquerda); G- botão floral; H- fruto maduro (A-C- Thomas 11029; D-G- Fiaschi 1850; H- Fiaschi 1909).

ovadas a orbiculares, ápice acuminado, imbricado; pétalas 8-9 × 4-5 mm, ovadas, conatas na base; estames 5, 4-4,5 mm compr., adnatos ca. $2 \mathrm{~mm}$ da base das pétalas; pistilo ca. $4 \times 3 \mathrm{~mm}$; ovário 5-locular. Frutos ca. 1,6 × $2 \mathrm{~cm}$, globosos; epicarpo verde- purpúreo, com pequenas máculas amarelo-claras; sementes vermelhas.

Ocorre na América Central (Costa Rica, Nicarágua e Panamá) e na América do Sul (do Suriname à Bolívia, incluindo o Brasil) (Machado \& Lopes 2000). 


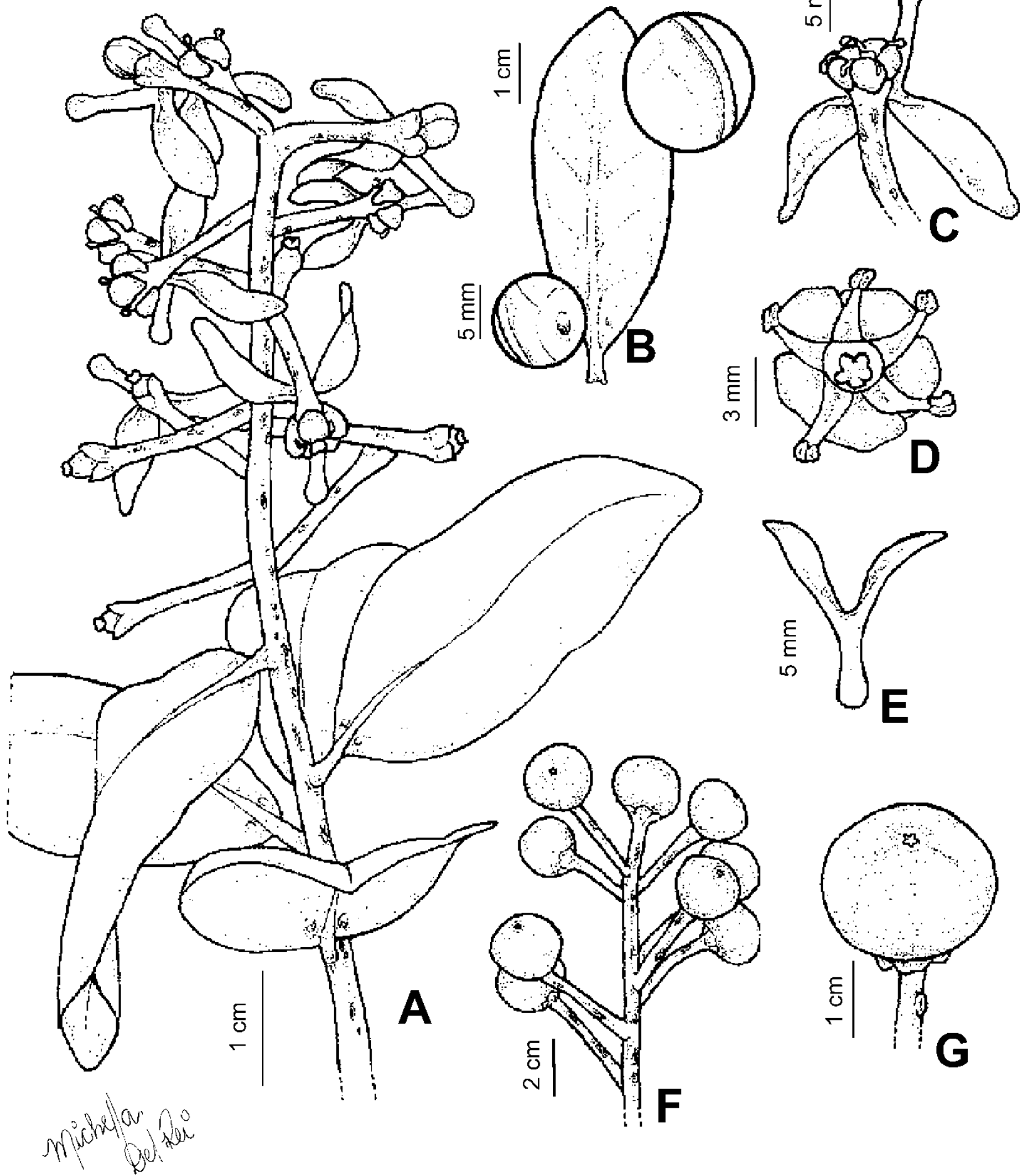

Figura 10. Souroubea guianensis: A- ramo com inflorescência; B- folha adulta, com detalhe da glândula e da margem; C- botão floral associado ao nectário; D- flor; E- nectário; F- ápice da infrutescência; G- fruto maduro (A, C-E- Jardim 2612; B, F-G- Paixão 1096).

No Brasil, ocorre nas Regiões Norte e Nordeste (Souza 2012). D10, E8, E9, F8, F9, G8, H8, I8 e J8: floresta ombrófila, mata ciliar e restinga arbórea. Floresce de novembro a fevereiro e frutifica de janeiro a maio.

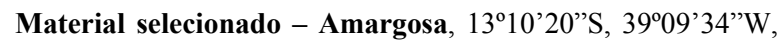
25 jan. 2007 (fl.), D. Cardoso et al. 1584 (CEPEC, HUEFS); Cairu, 1329'13”S, 3902'38”W, 9 dez. 1980 (bot.), L.A. Carvalho et al.

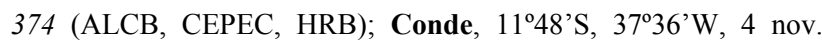

2001 (bot.), D.L. Santana et al. 675 (ALCB, CEPEC); Cravolândia, 1330'S, 39²4'W, 15 jan. 1994 (fl.), F. França et al.

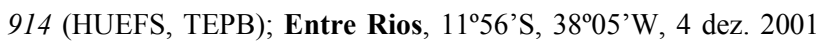
(bot.), M.L. Guedes et al. 7377 (ALCB, JPB); Igrapiúna, 13053'15”'S, 39²0'39'W, 18 dez. 2001 (fr.), M.L. Guedes et al. 9291 (ALCB, CEPEC); Ilhéus, 14³5'10"S, 3907'25”'W, $170 \mathrm{~m}$, 19 dez. 2004 (bot. e fl.), A.M. Amorim 4555 (CEPEC); Itacaré, 14¹6'39”S, 3859'48”W, 27 jan. 1982 (bot.), T.S. Santos et al. 


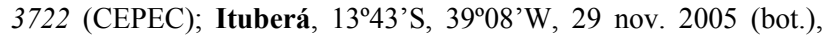
R.M. Valadão \& M.L. Guedes 172 (ALCB); Maraú, 14²'07'S, 3902'03"W, 1 fev. 2000 (bot. e fl.), J.G. Jardim et al. 2612 (CEPEC); Nilo Peçanha, 13³5'58”S, 3906’25”'W, 22 nov. 1985 (bot.), L.A. Silva \& T.S. Santos 1968 (CEPEC); Prado, 1700'47'S, 39¹2'06”'W, 30 out. 2002 (bot.), J.G. Jardim et al. 4029 (CEPEC, HUEFS); Santa Cruz Cabrália, 5 jan. 1972 (bot. e fl.), A. Eupunino 150 (CEPEC); São Felipe, 12050'50"S, 3905'22”W, 26 dez. 1956 (bot. e fl.), R.P. Lordêlo 56-665 (ALCB); São Sebastião do Passe, 12³2'28'S, 38²2'51'"W, 25 mar. 2001 (fr.), M.L. Guedes et al. 9736 (ALCB); Taperoá, 1332'17’S, 3905'55"W, 8 dez. 1980 (fl.), A.M. Carvalho et al. 360 (CEPEC); Ubaitaba, 14¹8'45"S, 39¹9'24”'W, 13 dez. 1967 (bot.), S.G. Vinha \& A. Castellanos 19 (CEPEC); Una, 15¹7'36”'S, 39'04'31'W, 23 dez. 2008 (bot), J.G. Jardim \& A. Jardim 5450 (CEPEC); Uruçuca, 14²5'24”'S, 3903'38’'W, 12 mar. 1995 (fr.), W.W. Thomas et al. 10903 (CEPEC); Valença, 13²2'13”'S, 3904'23”'W, jan. 1952 (fl.), G.C.P. Pinto 52-44 (ALCB); Wenceslau Guimarães, $13^{\circ} 36^{\prime} \mathrm{S}, 39^{\circ} 43^{\prime} \mathrm{W}, 14$ maio 1992 (fr.), W.W. Thomas et al. 9313 (CEPEC).

Souroubea guianensis é facilmente reconhecível dentre as espécies de Marcgraviaceae do estado por apresentar flores com nectário séssil com base biauricular vermelha, inserido logo abaixo do receptáculo. De Roon (1975) reconheceu três subespécies, todas representadas no Brasil (Souza 2012). Entretanto, esses táxons infraespecíficos não foram validamente publicados.

\section{AgRADECIMENTOS}

Agradecemos aos curadores dos herbários visitados pela Disponibilização dos materiais e ao HUEFS pelo empréstimo concedido. Ao Conselho Nacional de Desenvolvimento Científico e Tecnológico (CNPq) pela bolsa de Produtividade (processo 309303/2009-5) concedida ao último autor e pelo financiamento obtido no Edital Universal (processo 481592/2009-1); à Fundação de Amparo à Pesquisa do Estado da Bahia (FAPESB) pelo financiamento obtido no Edital de Pesquisas (processo APP0041/2009) e pelas duas bolsas de Iniciação Científica (programa PIBIC/UESC) concedidas à primeira autora.

\section{REFERÊNCIAS}

Amorim, A.M.; Jardim, J.G.; Lopes, M.M.M.; Fiaschi, P.; Borges, R.A.X.; Perdiz, R.O. \& Thomas, W.W. 2009. Angiospermas em remanescentes de floresta montana no sul da Bahia, Brasil. Biota Neotropica 9: 313-348.

De Roon A.C. 1975 Contributions Towards a Monograph of the Marcgraviaceae. Rijksuniversiteit Utrecht XIV, Utrecht.

Delpino F. 1869. Ulteriori osservazioni e considerazioni sulla dicogamia nel regno vegetale. Atti della Società Italiana di Scienze Naturali e del Museo Civico di Storia naturale di Milano 12: 182-210.

Dressler, S. 2004. Marcgraviaceae. In: N. Smith, S.A. Mori, A. Henderson, D.W. Stevenson \& S.V. Heald (eds), Flowering
Plants of the Neotropics. Princeton University Press, Princeton, p. 236-238.

Ferreira, G.L. 1995. Estudo taxonômico das espécies brasileiras do gênero Norantea Aublet (Marcgraviaceae). Arquivos do Jardim Botânico do Rio de Janeiro 33: 9-53.

Giraldo-Cañas, D. 1999. Las Marcgraviaceae de la Amazonia colombiana: estudio Preliminar sobre su diversidad, distribución y fitogeografía. Darwiniana 37: 15-24.

Giraldo-Cañas, D. 2001a. Schwartzia brasiliensis (Marcgraviaceae), nueva combinación. Caldasia 23: 341-342.

Giraldo-Cañas, D. 2001b. Una nueva especie de Schwartzia (Marcgraviaceae) de la vertiente occidental andina de Colombia y Ecuador. Caldasia 23: 383-388.

Giraldo-Cañas, D. 2001c. Dos nuevas especies de Schwartzia (Marcgraviaceae) de Colombia. Revista de la Academia Colombiana de Ciencias Exactas, Físicas y Naturales 25: 477482.

Giraldo-Cañas, D. 2002. Una nueva especie de Marcgravia, grupo Galeatae (Marcgraviaceae) de la Cordillera Oriental y catálogo del género para Colombia. Revista de la Academia Colombiana de Ciencias Exactas, Físicas y Naturales 26: 367-371.

Giraldo-Cañas, D. 2003. Revisión de las especies colombianas del género Schwartzia (Marcgraviaceae). Caldasia 25: 1-21

Giraldo-Cañas, D. 2004. Las especies del género Schwartzia (complejo Norantea, Marcgraviaceae) en Brasil. Darwiniana 42: 169-175.

Giraldo-Cañas, D. 2007. Un nuevo género de la familia neotropical Marcgraviaceae (Ericales) y circunscripción del complejo Norantea. Caldasia 29: 203-217.

Giraldo-Cañas, D. 2011. Estudios morfológicos y taxonómicos en el complejo Norantea (Marcgraviaceae): Revisión de Norantea, Pseudosarcopera y Schwartzia. Biblioteca José Jerónimo Triana 22: 1-176.

Giraldo-Cañas, D. \& Fiaschi, P. 2005. Las Marcgraviaceae (Ericales) de Brasil: Las especies del complejo Norantea. Caldasia 27: 173-194.

Machado, I.C. \& Lopes, A.V. 2000. Souroubea guianensis Aubl.: quest for its legitimate pollinator and the first record of tapetal oil in Marcgraviaceae. Annals of Botany 85: 705-711.

Peixoto, A.B.F. 1985. Marcgraviaceae. In: J. Rizzo (ed.), Flora do Estado de Goiás. Coleção Rizzo (J.A. Rizzo, coord.). Vol. 5. Editora da Universidade Federal de Goiás, Goiânia, p. 1-32.

Picca, P. \& Giraldo-Cañas. D. 1999. Una nueva espécie de Marcgravia (Marcgraviaceae) de la Amazonia colombiana. Hickenia 2: 293-298.

Reitz, P.R. 1968. Marcgraviaceae. In: R. Reitz (ed.), Flora Ilustrada Catarinense, I parte, fascículo Marc. Herbário Barbosa Rodrigues, Itajaí, p. 1-12.

Sano, P.T. \& Pirani, J.R. 2004. Flora de Grão-Mogol, Minas Gerais: Marcgraviaceae. Boletim de Botanica da Universidade de São Paulo 22: 303-304.

Souza, V.C. 2012. Marcgraviaceae In: Lista de Espécies da Flora do Brasil. Jardim Botânico do Rio de Janeiro. Disponível em http://floradobrasil.jbrj.gov.br/2012/FB000158; acesso em 10 out. 2012.

Stannard, B.L. 1995. Marcgraviaceae. In: B.L. Stannard (ed.), Flora of the Pico das Almas, Chapada Diamantina, Bahia, Brazil. Royal Botanic Gardens, Kew, p. 432-433.

Wittmack, L. 1878. Marcgraviaceae. In: C.F.P. Von Martius, A.G. Eichler \& I. Urban (eds), Flora Brasiliensis. Vol. 12, pars 1. München, Wien \& Leipzig, p. 213-258, t. 40-51. 


\section{LISTA DE EXSICATAS}

Amorim A.M. 1179 (4.1), 1250, 3646 (1.1), 3941 (4.1), 4250 (1.2), 4310 (4.1), 4505 (1.1), 4552 (1.2), 4555 (4.1), 4737 (1.1), 5134 (1.2), 5744, 6679 (1.1), 6792 (3.2), 7460 (1.2); Araújo, A.P. 295 (3.2); Arbo, M.M. 7147 (1.1); Argolo, A. 4 (1.1); Bautista H.P. 287 (1.1), 1467 (2.1), 1820 (1.1); Belém, R.P. 988 (1.1), 3040, 3474 (4.1); Bispo, R. s.n. ALCB 65303 (4.1); Cardoso, D. 1584 (4.1), 12053 (3.2); Carneiro-Torres, D.S. 192 (4.1); Carvalho, A.M. 360, 1430 (4.1), 4997 (1.1), 5335 (4.1); Carvalho, L.A. 374 (4.1); Conceição, A.A. 1471 (2.1); Grupo Pedra do Cavalo 1000 (3.2); Daneu, L.H. 420 (3.4), 470 (4.1); Eupunino, A. 150 (4.1); Ferreira, M.C. 892 (1.1), Fiaschi, P. 1772 (1.2), 1850, 1909 (3.4), 2138, 2329 (1.1), 2755 (3.2); França, F. 911 (3.2), 914 (4.1); Ganev, W. 811 (3.1); Guedes, M.L. 561 (3.2), 3645 (1.1), 1009, 7230 (3.2), 7377, 9291,9736 (4.1); Hage, J.L. 653 (1.1), 1473 (4.1), 5744 (1.1); Harley, R.M. 17940 (3.2), 25726,26538 , 27042 (3.1); Hatschbach, G. 59728 (3.4); Jardim, J.G. 956, 2612, 4029 (4.1), 4308 (3.4), 4697 (1.2), 4854 (1.1), 5450 (4.1); Lopes, M.M. 337 (1.2); Lôrdelo, R.P. 56-145 (1.1), 56-665 (4.1); Lopes, M.M.M. 337 (1.2), 453, 1585 (3.2); Magalhães, L.C. 11 (4.1); Martinelli, G. 8894 (4.1); Matos, E. 739 (1.1); Miranda, A.M. 3000 (2.1); Monteiro, R.F. 627 (3.1); Moraes, A.O. 110 (3.2); Moraes, P.L.R. 3092 (3.1); Oliveira M. 3048 (3.1); Orlandi, R.P. 722 (3.2); Paixão, J.L. 1096 (4.1); Perdiz, R.O. 254 (1.1), 416 (1.2); Pinto, G.C.P. $52-28$ (3.2), $52-44$ (4.1), 8969 (3.2); Popovkin, A.V. 1043 (1.1); Queiroz, L.P. 452 (3.2), 10906 (2.1); Ribeiro, T. 341 (3.1); Santana, D.L. 670 , 675 (4.1); Santos, T.S. 771 (1.1), 866 (1.2), 2186 (3.2), 2223 (4.1), 2682 (1.1), 2854 (4.1), 2895 (1.1), 3481 (3.2), 3529 (4.1), 3653 (1.1), 3722, 4544 (4.1); Silva, B.M. 117 (3.2); Silva, L.A. 1968 (4.1); Soares, R. 1166 (4.1); Sobral, M. 5769 (4.1); Souza, E.B. 1584 (2.1); Souza, V.C. 26007 (3.1); Thomas, W.W. 9313,10903 (4.1), 11029 (3.3), 14217 (1.2); Valadão, R.M. 172 (4.1); Vinha, S.G. 19, 121 (4.1). 